\title{
Sección Abierta \\ EL MÁRTIR ARMENIO: LA CONSTRUCCIÓN POLÍTICA DE UNA FIGURA EJEMPLAR DESPUÉS DEL GENOCIDIO (1915-1918)
}

\author{
Carlos Antaramián Salas
}

Resumen: La figura ejemplar del mártir ha tenido un papel fundamental en la política de memoria estructurada por las comunidades armenias después del genocidio (1915-1918); funge como imagen de honra nacional que ayuda al mantenimiento de la identidad armenia en espacios de asimilación (países anfitriones de la diáspora). En este artículo presento las transformaciones por las cuales ha transitado esta figura a partir de su puesta en escena cada 24 de abril, fecha de conmemoración del genocidio que se realiza en casi todas las comunidades armenias asentadas en los cinco continentes, luego del exilio forzado. La política de memoria que se articula en el seno de la diáspora armenia posibilita entender el uso de la figura del mártir como estrategia para calificar tanto a las víctimas del genocidio como a los jóvenes que se inmolan en prácticas terroristas.

Palabras claves: genocidio, martirio, figuras ejemplares, políticas de memoria, armenios.

Enviado a dictamen: 30 de septiembre de 2008 Aprobación: 30 de noviembre de 2008.

Dr. Carlos Antaramián, doctor en Antropología Social por El Colegio de Michoacán, estancia posdoctoral Universidad Autónoma Metropolitana-Xochimilco, Comunidades armenias, estudios sobre genocidios, Antropología visual, correo electrónico: cantaramian@gmail.com.
Abstract: The key figure of the martyr has had an important role in the structured memory of the Armenian communities after the Genocide (1915-1918); it is a national hero that helps to maintain the Armenian identity in the host societies. In this paper I show the several transformations of this figure specially in the ceremonial acts commemorating the Genocide every April 24th. The memory policies articulated within the Armenian communities in the Diaspora, helpus to understand the use of the martyr key figure as an strategy to name not only the victims in the Genocide, but also the young Armenians who offer their lives in terrorist practices.

Key words: Genocide, martyrdom, key figures, memory policies, Armenians.

$\mathrm{E}$ n los últimos decenios del siglo XIX los armenios ${ }^{1}$ (habitantes de tres imperios: Persa, Otomano y zarista) tuvieron un despertar político, social e intelectual que hizo posible su incorporación al cauce de las ideas occidentales (Zekiyan, 1999). Su mundo religioso, que los había formado y definido desde su conversión al cristianismo en el siglo IV, fue sacudido por la fuerza de las reformas políticas, la educación moderna y el nacionalismo. Este último era una expresión nueva, moderna, en la cual los armenios intentaron manifestarse y expresarse no sólo como minoría religiosa sino también como nación. El Imperio Otomano, que gobernaba a la 
mayor parte de quienes se denominaban armenios, no se quedó con los brazos cruzados ante este despertar, sobre todo porque el pueblo turco también transitaba por la misma construcción moderna de nación.

Fue entonces cuando se instrumentó una serie de políticas de control y subyugación articuladas por los gobiernos del sultán Abdul-Hamid II (1876-1909) y de los jóvenes turcos (1908-1918) en contra del despertar y la modernización armenias. Fueron una especie de ensayos similares al pogromo antisemita centroeuropeo: violencia dirigida hacia la población armenia en ciudades identificadas como "revolucionarias". Sin distinción de edad, sexo o filiación política, sino por el hecho de haber nacido armenios y, por tanto, ser acreedores a la causalidad diabólica que suelen animar las minorías; los armenios fueron responsabilizados de los males del Imperio Otomano en desintegración y de las amenazas de injerencia europeas; también eran vistos como los autores de una conspiración o complot que tenía como fin la destrucción del poder Otomano establecido.

Las masacres de 1895-1896 - que produjeron la muerte de entre 100 y 200 mil armenios ${ }^{2}$ y cerca de 500 mil huérfanos - fueron el inicio de una serie de políticas violentas (de exterminio premeditado) en contra de la minoría armenia. Posteriormente, durante el primer año de gobierno de los jóvenes turcos (tras el derrocamiento del sultán en 1909), éstos permitieron las masacres en la ciudad mediterránea de Adaná, donde murieron entre 20 y 25 mil armenios.

La política de subyugación y exterminio de la minoría cristiana armenia, considerada de segunda clase y conocida como "la cuestión armenia", produjo su internacionalización y logró que las potencias europeas plantearan demandas al Imperio Otomano en busca de mejoras para las minorías, las cuales nunca se cumplieron. Esta situación también ocasionó la emergencia de los primeros partidos políticos armenios de carácter clandestino: el Partido Liberal Armenagán (1885) en Van (Imperio Otomano), el Partido Marxista Hnchakián (1887) en Ginebra (Suiza) y la socialista Federación
Revolucionaria Armenia o Tashnaksutiún (1890) en Tiflis (Imperio zarista). Más tarde se crearía el Partido Demócrata Liberal de la burguesía, conocido como Ramgavar (1908) en Constantinopla (Imperio Otomano). ${ }^{3}$

La entrada en la Primera Guerra Mundial del Imperio Otomano al lado de Alemania y Austria-Hungría y en contra de Rusia, Francia y Gran Bretaña dividió a los armenios en dos campos antagónicos. Fue la ocasión para el gobierno de los jóvenes turcos de inculpar a los armenios, bajo el manto de la guerra, de sedición y de ser aliados de los enemigos rusos. Lo anterior sirvió de pretexto para trasladarlos a lugares donde no fueran peligrosos para la seguridad del Estado - como el desierto de la provincia siria-; así inició una política de deportación y exterminio tendiente a eliminarlos como pueblo, es decir, se programó un genocidio.

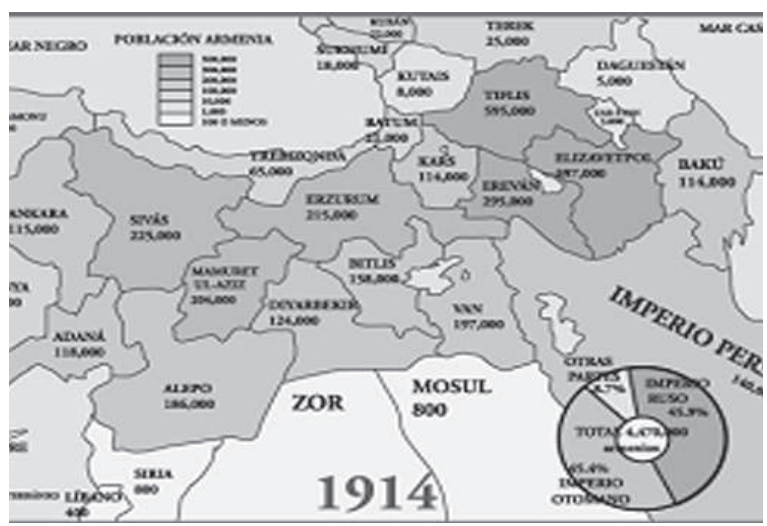

Población armenia en 1914.

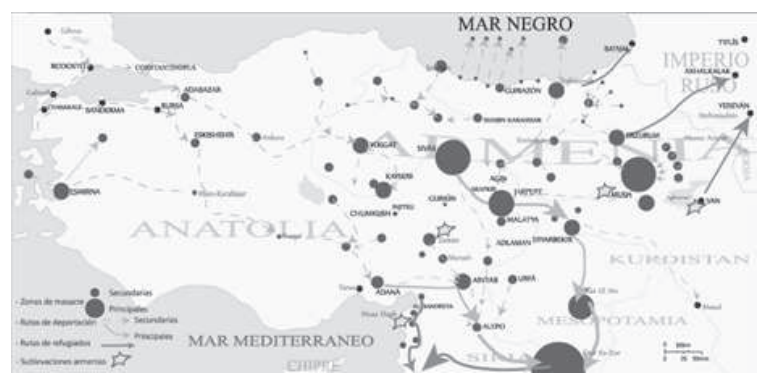

Principales rutas de deportación y zonas de masacre del genocidio armenio 1915-1918. 


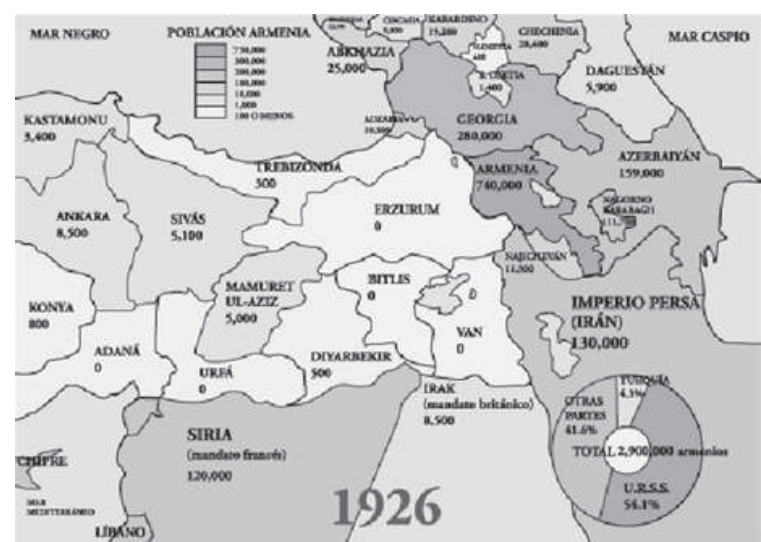

Población armenia en $1926 .{ }^{4}$

El 24 de abril de 1915 dio inicio la deportación de entre 300 y 600 personas de la elite intelectual y política de Constantinopla (hoy Istanbul), con destino a Anatolia (la actual Turquía asiática) donde fueron asesinados. Posteriormente ocurriría la emasculación o eliminación de los hombres en edad de combatir (18-45 años) quienes, requisados para cumplir con el servicio militar, fueron obligados a trabajos forzados y aniquilados en puestos de retaguardia, fusilados o enterrados en trincheras construidas por ellos mismos (Morgenthau, 1919). La tercera etapa fue la deportación de ancianos, mujeres y niños mediante un plan con tiempos establecidos para cada ciudad de las provincias armenias, combinando marchas forzadas con privaciones de agua y alimento, pillajes, violaciones y masacres colectivas antes de llegar a sus futuras fosas comunes en los desiertos de Deir ez-Zor y Mesopotamia. Del millón y medio de víctimas - casi 70 por ciento de la población armenia del Imperio Otomano - la mitad murió de sed, hambre, enfermedades y cansancio por las marchas forzadas; otra mitad murió por vejaciones en los caminos, ahogadas en el caudaloso Éufrates o finalmente masacradas en el desierto. De los dos millones 100 mil armenios que aproximadamente habitaban en el Imperio Otomano, hubo cerca de 600 mil sobrevivientes quienes se convirtieron, en su mayoría, en refugiados.

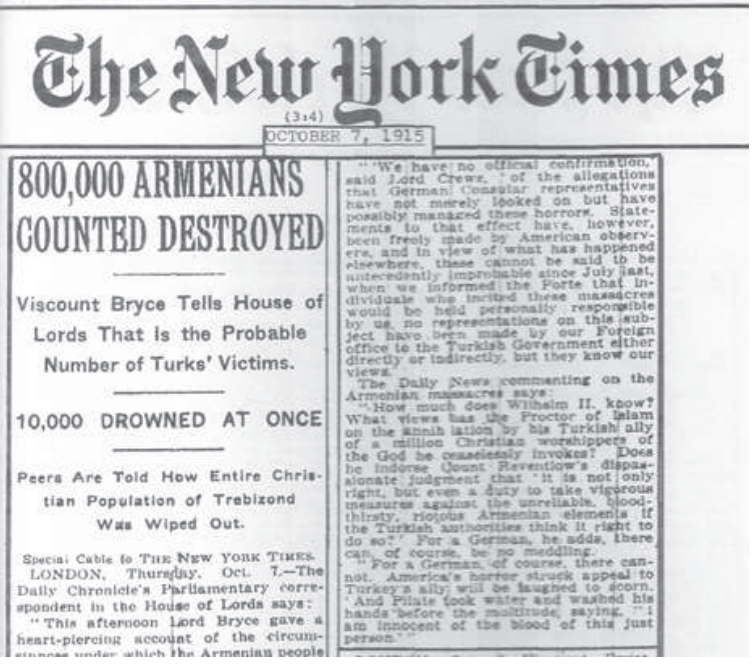

\section{Extracto del periódico New York Times del 7 de octubre} de 1915, páginas 3 y 4.

El holocausto padecido, como toda experiencia trágica, produce emociones profundas y desgarradoras; es referido por los sobrevivientes armenios bajo formas que recuerdan la pasión de Cristo o historias de martirologio de los antiguos testigos cristianos (Tölölyan, 1987a: 93). La construcción de narrativas traumáticas post-genocidas hacen un uso extensivo del Gólgota y el millón y medio de víctimas son consideradas como mártires. La historia del genocidio armenio se articula en dos niveles: el nacional y el familiar. El primero refiere la masacre de una nación y la pérdida de la patria; el segundo recuenta la historia de cómo los familiares murieron y establece un recuerdo nostálgico por el pueblo de origen. 


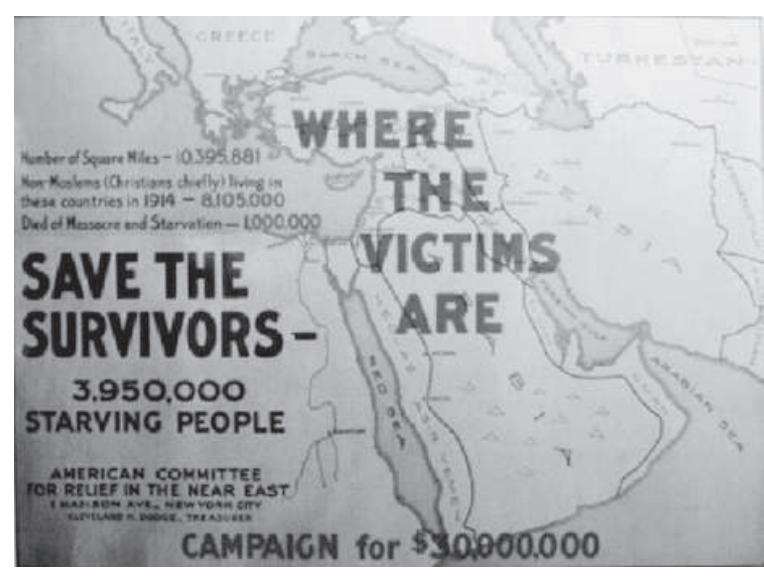

Póster del Armenian Committee for Relief in the Near East

A partir de esta gesta martyrum se extraen los personajes que conformarán el mundo performativo armenio posterior al genocidio. A pesar de que prevalece una distinción entre mártir, confesor y víctima, la construcción y rememoración que hacen los armenios de su holocausto es articulada con base en la tradicional figura ejemplar del mártir. En el caso particular armenio, el mártir se sacrifica por una dualidad: la patria y la religión.

Para los armenios la santificación de héroes quienes dieron su vida por la patria-religión es un proceso que se remonta a su conversión al cristianismo (30l d.C). ${ }^{5}$ Tanto la primera como la segunda guerras en defensa del cristianismo ocurrieron en Armenia; la segunda fue un combate en la planicie de Avarair en 45l d.C. entre armenios y persas, conocida como Vartanantz; de aquélla batalla emergió un héroe casi mítico para la identidad armenia, el mártir-guerrero Vartán, desde entonces figura ejemplar y pieza clave en la literatura armenia medieval y romántica, cuya historia se repite en toda escuela de la diáspora armenia. Para el cristianismo del subyugado pueblo armenio la violencia y el martirio han sido una constante en su historia, y a este último recurre para la creación de sus personajes admirables.

El símbolo, modelo o paradigma del mártir está enraizado en la cultura armenia. Esa es la razón por la cual los armenios recurren a una interpretación y explicación del evento catastrófico genocida con base en esa figura ejemplar; sin embargo, durante el siglo XIX el mito del mártir-guerrero entró en un proceso de secularización hasta convertirse en una causa que tiene en lo patriótico-político su motivación más importante.

En dicho proceso tuvieron una participación importante los guerrilleros-patriotas conocidos como fedayín, figura revolucionaria emanada principalmente del Tashnaksutiún (Federación Revolucionaria Armenia). Su nombre en persa designa a "aquél que se ha comprometido" o "aquél que es sacrificado"; es un hombre armado quien combate en contra del injusto régimen Otomano que mantiene subyugado al pueblo armenio. El fedayín dedica su vida al pueblo; quiere despertarlo con su acción patriótica y, sobre todo, con su disponibilidad para la muerte.

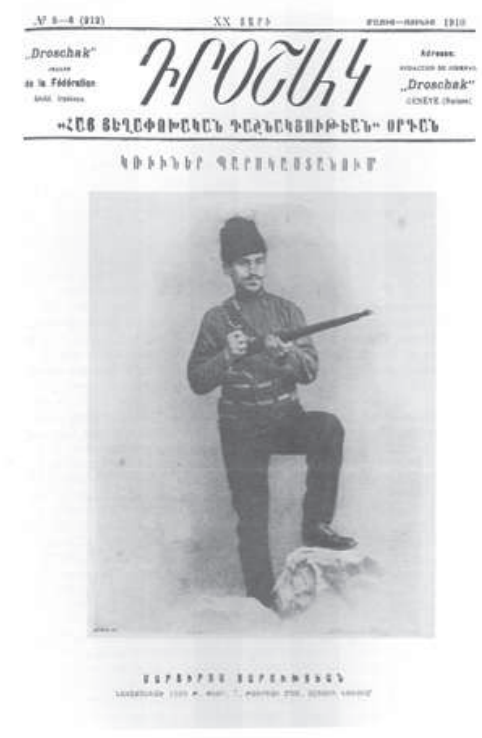

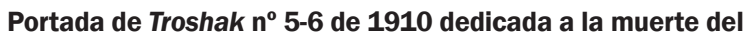
fedayín Martirós (es nombre propio) y la participación de la Federación Revolucionaria Armenia en Irán (en Dasnabedian, 1988: 96). 
Entre los fedayines la causa armenia, como en el caso de Vartán, no es exclusivamente la defensa de Cristo sino también una resistencia al orden político opresor. La imitatio Christi constituye una invitación suprema y ejemplar que permanece en los grupos de fedayines. La tradición del martirio es utilizada por éstos para ofrecer una explicación a su sacrificio; pero también es reinterpretada para la construcción de nuevas figuras que asimismo se ofrendan y que serán usadas de manera política en aras de justicia en el futuro.

La política de la memoria de injusticia va transformándose conforme los escenarios y las nuevas generaciones cambian. Pero el martirio, como un estigma del pasado, es portado y transmitido por las generaciones venideras. La tradición del mártir-héroe es fuente de legitimidad. Su utilización permite apelar a una historia que ha sido idealizada y modificada su forma de representación, especialmente por la influencia del Siglo de las Luces; pero no así su forma y significación esenciales que permanecen intactos.

La ejemplaridad de esta figura simbólica encarna fenómenos colectivos de adhesión pasional o de incorporación identitaria que orienta prácticas y creencias posibilitadoras de emociones y acciones. Las comunidades ( $\mathrm{y} / \mathrm{o}$ sus dirigentes) hacen de estos paradigmas humanos ejemplos a seguir. Desde luego, en el caso de los mártires del genocidio no se pretende hacer de su muerte un ejemplo; al contrario, se trata de hacer imposible el retorno de situaciones traumáticas parecidas. Lo que resulta ejemplar para los armenios no es su agonizante muerte sino el legado de su fe que, como los santos, según la hagiografía cristiana, son más "admirables que imitables" (Albert, 2001: 18).

El esquema de valores articulador de la figuraarquetipo del mártir sí es un ejemplo a seguir, así como la fe y el sacrificio por los que tuvo que pasar por y para el "nosotros" (armenios) en contra del "ellos" (turcos), a semejanza de Cristo. Sin embargo, no es lo mismo ser un modelo construido en el siglo I que otro del Renacimiento o bien uno fabricado en el siglo XX. Mientras la ejemplaridad de los primeros siglos de nuestra era se edificaba exclusivamente bajo modelos religiosos, los paradigmas de santidad o martirio de la época de la Reforma europea ya combinaban religiosidad con persecución política. Finalmente, en los más recientes siglos XIX y XX predomina una santificación de héroes de estirpe nacional para satisfacer proyectos de construcción de Estado-nación. Las figuras de santo, héroe o mártir han tenido una transformación que se origina en el modelo religioso y que llegan al secular pero nunca han dejado de tener una intención política. Y es que las capacidades movilizadoras del heroísmo y del martirio se sustentan en tradiciones muy arraigadas que permiten transitar sin dificultad de la esfera religiosa a la política secularizada.

La construcción de la ejemplaridad y su estrecha relación con formas de dominación y poder, como dice Balandier (1992), se hace y conserva al producir y organizar imágenes en cuadros ceremoniales. Las elites en busca de legitimidad y/o reconocimiento no sólo se apropian de la tradición sino que también la reinventan, moldeándola en función de sus intereses. De manera similar, las elites también hacen uso de la ejemplaridad y construyen formas ejemplares. Dichas figuras se encuentran en el pasado y las elites sólo necesitan echar mano de la historia para reincorporarlas a sus objetivos inmediatos (Giordano, 2001); o bien, encontrar en el presente figuras que respondan claramente con lo que colectivamente se ha considerado ejemplar en otro momento. La ejemplaridad depende no sólo de las elites contendientes en las arenas políticas disputando variados modelos ontológicos, sino que la utilización de modelos de ejemplaridad del pasado son utilizados de distinta manera por grupos culturales diversos. ¿En qué radica que un grupo sociocultural escoja al mártir (al santo o al revolucionario) como modelo de ejemplaridad?

Desde la creación del primer partido político armenio en la ciudad de Van en el centro de Anatolia en 1885 
(Armenagán), hasta el exilio y la multiplicidad de comunidades diaspóricas de nuestros días, los partidos políticos armenios han jugado un papel central en la historia del pueblo armenio. Han transitado por tres acontecimientos que he considerado hitos de primera importancia:

1. 1. El genocidio (1915-1918) que diezmó a la población y ocasionó la dispersión catastrófica de los sobrevivientes;

2. 2. La creación de la primera República armenia (28 de mayo de 1918-diciembre de 1920) bajo la conducción del partido Tashnaksutiún hasta convertirse en un gobierno en el exilio; debido a:

3. 3. La sovietización de la República y el ascenso del partido comunista en la dirección del destino de la reducida "tierra Armenia" (29 de noviembre de 1920 a 21 de septiembre de 1991).

A estos hitos históricos y periodos de accionar partidista podemos agregar dos eventos que influyeron considerablemente en la transformación de la fecha infeliz o maldita (dies irae) armenia: primero, las actividades de grupos vengadores que funcionaron como justicieros contra los responsables del genocidio (1921-1923) y de grupos terroristas en contra de representantes-diplomáticos del gobierno turco quienes a su vez niegan el hecho genocida (1975-1988); segundo, el cincuentenario del genocidio armenio en 1965 que provocó la movilización masiva de los armenios dispersos por el mundo en busca del reconocimiento del acto genocida por parte de la comunidad internacional. Estas fechas permiten establecer una delimitación de los momentos de quiebre de las conmemoraciones armenias para recordar el genocidio. He establecido los siguientes cortes condensadores:

1. 1921-1964. Las conmemoraciones silenciosas

2. 1965-1975. Las manifestaciones por el cincuentenario y la lucha por el reconocimiento.

3. 1975-1988. Las ejecuciones de los mártires terroristas.
El poder, dice Balandier, "utiliza medios espectaculares para señalar su asunción en la historia (conmemoraciones), exponer los valores que exalta (manifestaciones) y afirmar su energía (ejecuciones)" (1992: 23). En este trabajo se exponen tres puestas en escena espectaculares. En el primer corte me abocaré a la conmemoración, en el segundo a las manifestaciones y en el tercero a las ejecuciones terroristas, pero siempre con la intención de mostrar cómo la figura ancestral y tradicional del héroe-mártir inmolado es utilizada de manera política en aras de la memoria, especialmente en los días de conmemoración del genocidio armenio.

Al hacer una revisión histórica de estas conmemoraciones, busco no sólo propiciar una reflexión exclusivamente cronológica, sino que intento indagar aún más en el sentido y significación de la figura central de la rememoración. Mi interés principal en establecer estos periodos radica, entonces, en tener un control metodológico más adecuado para mostrar cómo los hitos históricos, que influyen en el accionar partidario, implican necesariamente una forma diferente en la construcción de esa figura ejemplar que ayuda a la imaginación de una identidad nacional en peligro. Este peligro consiste en una serie de miedos y reclamos de las comunidades armenias dispersas y que, de manera general y deducida a partir de entrevistas durante mi trabajo de campo (2000-2005), he establecido los siguientes:

a. miedo a enfrentar una situación de exilio,

b. a la asimilación en los contextos del desplazamiento,

c. a la pérdida de la identidad,

d. al sentimiento de impotencia política por la falta de un Estado que los represente y proteja,

e. al reclamo de justicia en contra de los responsables del genocidio,

f. a la devolución del territorio usurpado tomando como referencia el mapa establecido en 1920 por el presidente estadounidense Woodrow Wilson que estipula una Armenia diez veces más grande que los 29 mil 800 kilómetros cuadrados actuales, 
g. a la lucha en contra de los sucesivos gobiernos turcos que continúan negando el genocidio de 1915.

La figura ejemplar instrumentada en contra del peligro y que ayuda a la cohesión nacional armenia es la de mártir; pero dicha figura heroica o imago de honra nacional (Subirats, 2003: 31) es construida con base en la influencia de distintos acontecimientos, de manera que el uso político que se hace de la misma se modifica con el tiempo. La figura del martirio armenio ha pasado de su forma religiosa primigenia a una forma de combate por la causa armenia, pasando por periodos de silencio, combate terrorista y lucha armada. Este proceso de transformación de una figura ejemplar, una especie de revisión del icono o héroe fijado para la memoria, puede verse en las conmemoraciones, manifestaciones y actos terroristas realizados por armenios para recordar el genocidio sufrido en 1915, rememorado el infeliz día del 24 de abril.

Dicha fecha puede verse como una coyuntura institucionalizada en que la memoria colectiva del genocidio se activa nuevamente con el fin de recordar la catástrofe, como sucede también con las conmemoraciones de los aniversarios ligados a las dictaduras sudamericanas ${ }^{6}$ (Jelin, 2002: 245). El 24 de abril es un ritual público que hace presente el pasado y activa emociones y sentimientos profundos, los cuales se convierten en objetos de disputas y conflictos para definir el sentido y las formas de la memoria. A diferencia de las conmemoraciones sudamericanas, el 24 de abril es un ritual realizado unilateralmente ya que el heredero del gobierno represor, Turquía, intenta borrar cualquier mención del genocidio armenio, atacando directamente a esa "sagrada memoria" que tratan de conservar los armenios.

La agresión que buscaba la eliminación de lo "impuro" en las mentes genocidas de 1915 permanece en los dirigentes de los gobiernos turcos sucesores. Esa noxa (palabra latina que significa daño) que buscaba destruir de la faz de la tierra al pueblo armenio, continúa siendo estructurada por Turquía en escenarios internacionales, con base en la política del "nunca existentes". 7 Turquía ha instrumentado, con lúcida conciencia, la negación y desconocimiento del genocidio de antaño. Este hecho es fundamental para la identidad armenia. No es sólo construir la identidad para transmitir la cultura heredada, sino que existen fuerzas nocivas a las cuales es necesario combatir; la negación del genocidio ayuda para el mantenimiento combativo de una identidad desplazada. ${ }^{8}$ Muchas de esas reacciones a la negación se aprecian como representaciones para curar las heridas y buscar justicia. Al ser negados, me decía un entrevistado armenio, "la lucha se convierte entonces en un mantenimiento de eso que quedará de nosotros", es una lucha por mantener la memoria de la identidad construida.

¿Cómo se representa y se transforma la figura central y ejemplar de la conmemoración? Hobsbawn y Ranger (1984) indican que las tradiciones exitosas son aquellas que han logrado una periodicidad y que consiguen ser transmitidas de generación en generación. Al construirse, necesariamente dan paso a disputas internas y externas por definir la representación. De ahí que el objetivo sea apreciar las transformaciones de una figura de representación y su significación, a partir de su escenificación (o teatralización, dice Balandier) en las conmemoraciones anuales del 24 de abril, puesto que la memoria es el único camino posible para exorcizar muchos de los horrores vividos por el genocidio. El recuerdo permite vivir una catarsis de la experiencia y posibilita un olvido constructivo, que exige justicia. Como dice Todorov (1996: 121), la justicia "es uno de los campos desde el que se puede observar el modo en que un país [o una nación] gestiona la memoria de su pasado".

La necesidad de mantenerse unidos y poder conjurar el trauma existente en la comunidad ocurre de maneras diversas. Especialmente el trabajo de duelo se realiza en esa fecha conmemorativa que abre la caja de los recuerdos. El 24 de abril es el espacio más propicio para, de manera más intensa, observar las formas de exaltación que se articulan en las políticas de memo- 
ria, esas representaciones utilizadas por los armenios como respuesta al genocidio que provocó su exilio y deambular nostálgico.

Pero cuando se habla de genocidios y masacres desgarradoras, la distancia existente entre la realidad y la representación es importante; los horrores vividos llevan a sus víctimas y herederos a convivir con imágenes próximas a lo impensable, a lo inimaginable. Es ahí donde entra la figura ejemplar que posibilita ofrecer una explicación a la catástrofe y que ayuda a mantener una actitud de combate político por la injusticia: el martirio.

El papel de ese sacrificio ideal no se limita al mantenimiento de la causa, sino que también funciona como lazo entre la psicopatología o trauma vivido y la transmisión de la memoria colectiva, la cultura ancestral y los valores éticos en transformación. Los muertos, y la congoja sentida por ellos, es uno de los momentos más importantes del vínculo social. El acto de rememoración del 24 de abril es una acción colectiva de catarsis y de elaboración esencial en la transmisión cultural, incluidas sus tragedias y heridas. Y es que reunirse con otros que han sufrido la misma experiencia (como las madres y abuelas de la Plaza de Mayo en Argentina) para estar juntos, comer el tradicional plato de harissa (trigo) con carnero, oír la misa de réquiem y escuchar música y poemas que recuerdan a los mártires, ayuda a superar el trauma; pero también contribuye para transmitir una identidad sufriente y victimizada, especialmente en los difíciles contextos a donde han tenido que desplazarse los armenios y donde es necesaria la supervivencia.

\section{Las conmemoraciones silenciosas: 1921-1964}

Casi inmediatamente después de la sovietización de Armenia y el exilio de los miembros del Partido Tashnaksutiún (1920), apareció en la ciudad de Etchmiadzín - a pocos kilómetros de Yereván, sede del patriarca armenio- ${ }^{9}$ la resolución eclesial del "Catolicós de todos los armenios" Kevork V. (1911-1930) quien hizo "oficial” la fecha de rememoración del genocidio armenio.
El 11/23 [sic $\left.{ }^{10}\right]$ de abril ha sido definido como fecha nacional en memoria de nuestros innumerables mártires durante la guerra mundial. Su Santidad dice que esta fecha, habiendo sido determinada para toda la armenidad, ha sido registrada en el calendario de Etchmiadzín y recomienda agregarla en el calendario de Constantinopla (según el diario Hayastaní Gochnag, 24 de diciembre de 1921: 1600. Apud Karamanukián, Apuntes para una reconstrucción histórica de la conmemoración del 24 de abril, Uruguay, inédito).

Dicha resolución califica de mártires a las víctimas que, todavía en esa fecha, estaban siendo masacradas durante el genocidio al otro lado de la frontera. La respuesta eclesial se estructura con base en precedentes históricos; desde entonces posibilita tener una fecha de recordación que se celebra en las pocas iglesias que existen en la diáspora. Pero las reacciones en respuesta al genocidio no son exclusivamente de duelo y rezos recordatorios. No obstante ser la Iglesia la que dio inicio a una forma de recuerdo colectivo por los mártires, existen otras historias que se articulan como formas políticas de venganza y terror.

La operación punitiva Némesis, dirigida clandestinamente por la Federación Revolucionaria Armenia (Tashnaksutiún) bajo la mano de Shahan Natali ${ }^{11}$ no es, estrictamente hablando, un movimiento terrorista, sino que básicamente son actos de estricta justicia cometidos en nombre de una colectividad (Chaliand, 1982: 19), casi de manera individual y todavía lejos de cualquier organización pánica. La operación tenía como "blanco" a los principales responsables turcos de las masacres y la deportación. El abecé de su lista de verdugos a quienes infringiría castigo era al triunvirato que rigió durante el gobierno de los jóvenes turcos: Talaat, ${ }^{12}$ Enver $^{13}$ y Djemal, ${ }^{14}$ ministros del Interior, de la Guerra y de la Marina, respectivamente. Pero también incluyeron al ex primer ministro y presidente del Comité Unión y Progreso o partido de los jóvenes turcos, Saïd Halim, y al líder del Partido Musavat de Azerbaiján acusado de las 
masacres de 1918, Behboud Khan Jivanshir. ${ }^{15}$ También estaban incluidos en la lista del grupo Némesis el ideólogo Behaddin Shakir y el doctor Nazim Fehti, ${ }^{16}$ así como gobernadores de provincias otomanas que tuvieron un celo especial en las deportaciones, como Djemal Azmi, conocido entre los armenios como el verdugo de Trebizonda.

Halim, Shakir y Azmi fueron acribillados por Archavir Chiragián; el primero en Roma el 5 de diciembre de 1921 y los dos últimos en Berlín el 17 de abril de 1922 con la ayuda de Aram Yerganián. En 1973 Archavir Chiragián escribió en armenio la Deuda de sangre, sus memorias de justiciero, ${ }^{17} \mathrm{el}$ mismo año en que nuevos justicieros siguieron su camino y acribillaron a diplomáticos turcos, representantes de un gobierno que ha perpetuado la negación del genocidio.

La inspiración que produjo la operación Némesis de Tashnaksutiún es clara: como los mártires, los justicieros son héroes dispuestos a inmolarse por la patria y que serán futuros ejemplos para el accionar terrorista de los años setenta y ochenta. Su carrera no tiene como origen cometer un crimen, sino luchar en contra de la injusticia $y$, por consiguiente, llevan a cabo una especie de revancha. Se erigen en defensa y protección de la comunidad armenia y por ello son admirados, respetados y se les concede el calificativo de héroes (los hacen inmortales $y$, por lo tanto, conservan la memoria colectiva). Como señala Tölölyan (1987a, 1992), las acciones políticas como el terrorismo son parte de tradiciones inmersas en la cultura política y en los discursos de los miembros del Tashnaksutiún, principalmente, pero también se encuentran en otros grupos políticos armenios. Se trata de tradiciones que no mueren sino, más bien, se mantienen latentes en espera de condiciones políticas que las posibiliten.

Es en la década de los años veinte del siglo pasado cuando empieza a crearse en el pueblo armenio una política de memoria sobre el genocidio, la cual busca articular una continuidad en la tradición que se instituye. La escuela, la familia y la prensa jugaron un papel determinante para la transmisión del trauma a las generaciones venideras. Pero también la representación expresiva del acto genocida jugó un papel importante en esta etapa. En los años veinte y treinta se asistía a espacios de reunión comunitaria para conmemorar con un poderoso silencio. Al repetirse año tras año este periodo es el que determina la memoria ejemplar y gran parte del sentido simbólico del 24 de abril.

Desde 1921 y hasta 1964 la conmemoración y la historia del genocidio están destinadas a mantenerse casi exclusivamente dentro del grupo que lo padeció; por ejemplo, para las sociedades occidentales las masacres ocurridas en Armenia son eventos del pasado, de la historia antigua, exótica y casi olvidada (Chaliand, 1982: 57). ¿Cómo lograr y pedir que conozcan las masacres si no saben dónde se encuentra Armenia? En este periodo los armenios mantienen casi en secreto su dolor y su duelo; también se celebra con luto y pesar en muchas de las comunidades desperdigadas en los cinco continentes, informando a otros armenios sobre la realización de dichas actividades, dándoles continuidad dentro de una red de la imaginada comunidad dispersa.

En junio de 1930, en la sección "Armenios de América" del diario Hairenik (Patria) de Boston (Estados Unidos), apareció la siguiente carta firmada por un anónimo corresponsal desde la Ciudad de México:

\section{Celebración del luto de los mártires}

Ciudad de México. Nuestra colectividad también tuvo su recordación dedicada a la memoria de los innumerables mártires caídos en 1915 organizado por una comisión intercomunitaria, la comisión organizadora en el margen que le permitían sus esfuerzos presentó un programa inmejorable al público.

La sala donde se realizó la actividad era amplia y había sido decorada adecuadamente, sobre el escenario se había puesto una ofrenda de flores o una corona con un ribete negro, trajeron su participación a esta recordación la señora Proudián y los señores N. Simonián y H. Sarukhán. Quienes hablaron acerca del sentido de 
la recordación. Recitaron la señorita A. Mandikián, la pequeña Arpiné y el Sr. H. Arakelián. Cantaron las señoritas A. Kasabián, los señores H. Arakelián, V. Sarkisián, N. Odabachián y el pequeño Haik. Tanto lo recitado como los cantos fueron buenos, la señora B. Nshant participó interpretando dos temas al piano y la apertura y el cierre del acto estuvo a cargo del señor Levón Bodosián.

Lamentablemente algunos elementos no participaron de esta recordación. ¿Quién no ha tenido víctimas en su familia? No era necesario que por lo menos una vez al año nos uniéramos todos y de forma unida nos refiriéramos o evocáramos nuestros seres queridos perdidos para inspirarnos de su espíritu altruista. Nosotros no hemos llorado y no vamos a llorar jamás por las víctimas caídas en el altar de la libertad, por el contrario, les dimos nuestro ilimitado respeto para inspirar su espíritu libertario. Pero sí lloramos amargamente por aquellos elementos de las generaciones posteriores quienes no se unieron a nuestra recordación.

Un salón rentado en el centro de la Ciudad de México ${ }^{18}$ por una comunidad armenia que apenas alcanzaba las 340 personas. En la rememoración mencionada hay cantos, se recita y se pronuncian discursos sobre lo sucedido. También hay una ofrenda floral con ribete negro, muy parecido a los actos de conmemoración en la escuela Jrimian de Buenos Aires en los años cuarenta. ${ }^{19}$ Lo más relevante es la construcción de un ritual dedicado a los mártires por parte de miembros del Tashnaksutiún y en donde se recrimina la ausencia de otros grupos armenios y de las nuevas generaciones, motivo, ese sí, de lágrimas.

Karamanoukian (op.cit.) también cita un testimonio sobre el 24 de abril de 1929 en Montevideo donde se dice que la celebración es exclusiva del Tashnaksutiún, aunque refiere que los otros (hnchakian, ramgavar, etcétera) sí asistían, quizá en contra de su liderazgo central. Es claro que el partido Tashnaksutiún es el encargado de estructurar la rememoración dentro y fuera de Armenia. Las iglesias de la diáspora también comienzan a construir y realizar "celebraciones" por los mártires; en ellas se aglutina a miembros de todos los partidos y grupos. En ambos casos, se trata de conmemoraciones intramuros: son duelos internos y silentes en los cuales siempre hay dos personajes: el armenio martirizado y el culpable impune.

“㳊uiénno ha tenido víctimasen su familia?" Este poderoso vínculo social que dejan los mártires con su espíritu altruista, es decir, que se sacrificaron por "los armenios" (por la causa armenia), será una pieza importante en la transmisión generacional dispersa. Pero en el acto mencionado también se rinde homenaje y respeto a la inspiración libertaria, a las "víctimas caídas en el altar de la libertad": podrían ser los fedayines levantados en contra de la dominación turca, quizá las cuatro ciudades que mostraron resistencia durante el genocidio, ${ }^{20}$ o posiblemente se refiera a todas las víctimas de las "grandes masacres". Lo fundamental es que se trata de héroes-mártires que no fueron victoriosos sino que cayeron bajo un espíritu libertario.

La fusión de ideales (víctima-heroica) es una puesta al día de la historia armenia. La utilización política del genocidio es instrumentada en contra del peligro de la desaparición y ya podemos ver que su contenido es exclusivamente patriótico, el altar es nacional. Es el partido Tashnaksutiún el que se aboca a conformar una cultura política en la diáspora, al intercambiar las experiencias para conformar un todo sólido y unitario. En los años inmediatos al genocidio, la transmisión fue estructurándose en canales que articulaban la experiencia en una misma lógica de sentido identitario. La Iglesia se concentraba en la recordación de los mártires mientras que el Tashnaksutiún enfatizaba su espíritu libertario, la causa por la cual murieron en lugar de la muerte llana.

A pesar de que todos los grupos políticos armenios tengan esta fecha en común, no la recuerdan juntos. Luego de la sovietización de Armenia se crearon dos 
posturas sobre el proyecto de Estado que hizo que se dividieran claramente las comunidades en dos bandos antagónicos: quienes apoyaban la Armenia soviética (ramgavar, comunistas, hnchakián) y el Tashnaksutiún, es decir, los contra-tashnaksaganes pro-soviéticos y los pro-tashnaksaganes anti-soviéticos. Ese antagonismo ha impedido una conmemoración unificada en todas las comunidades armenias dispersas durante este periodo.

Una de las controversias más interesantes, expresión de dichos proyectos, es el de las banderas (la tricolor: ${ }^{21}$ rojo, azul y anaranjado de la Primera República gobernada por el Tashnaksutiún, y la de la Armenia soviética: roja con las iniciales de la República, que posteriormente tendría la hoz y una franja azul). Aunque parezca una nimiedad, fue el detonante para que la Iglesia Apostólica Armenia en Estados Unidos se dividiera en dos diócesis, cada una coordinada por un bando.

Tanto el grupo pro-soviético (hnchaks, ramgavares, comunistas y el Comité de Ayuda a Armenia Hayasdaní Oknutián Gomidéh o HOG) como las tashnaksaganes mantenían en sus comunidades espacios separados para hacer sus pic-nics o días de campo, sus celebraciones de liberación o independencia de Armenia (29 de noviembre y 28 de mayo, respectivamente), sus fiestas y reuniones dando lugar a dos burbujas de actividad armenias independientes. Sólo en la religión la comunidad se unía para la edificación de sus iglesias, la congregación, la manutención del pastor y la observancia de los días santos. Sin embargo, un acontecimiento acaecido en Estados Unidos y cuyas repercusiones llegaron a todos los confines de la dispersión armenia puede ser considerado como el momento cumbre de la discordia que da inicio a este odio que, en la plática informal entre algunos armenios, se refiere como la lucha entre Montescos y Capuletos.

Encontrándose Etchmiadzín (sede del supremo Catolicós armenio) dentro del Estado soviético, aunado a que en ese momento la sede catolicosal era controlada por los comunistas, se nombró al obispo de Manchester (Inglaterra) Levón Tourián como supremo prelado de la Iglesia Apostólica Armenia en América. Las iglesias de la diáspora tenían autonomía administrativa y sólo rendían lealtad a la Santa Sede de manera simbólica. Por logeneral, las condiciones de regulación de las iglesias se adecuaban a las peculiaridades de cada comunidad; además, en ese momentolagrey en Estados Unidos se encontraba dividida y muy sensible al manejo de símbolos y discursos, por lo que una actitud conciliadora era necesaria.

Sin embargo, una de las primeras acciones del arzobispo Tourián fue prohibir a los miembros del clero participar en los eventos públicos que se realizarían el 24 de abril de 1932, bajo el argumento de que una misa solemne de réquiem se haría en las iglesias y, por consiguiente, su presencia en los actos políticos - presumiblemente organizados por el Tashnaksutiún, como muestran los actos antes referidos- era innecesaria (Mesrobian, 2000: 143). Lo anterior significaba una clara confrontación con los simpatizantes de la Federación Revolucionaria Armenia.

Posteriormente, el prelado fue invitado a hablar en la exhibición de las nacionalidades en la Feria Mundial de Chicago el 1 de julio de 1933. En el podio estaba puesta la bandera tricolor (del Tashnaksutiún) y el Arzobispo rehusó hablar hasta no ser removida; al quitarse la bandera el pandemónium se desató. Una lucha entre los bandos se manifestó en los periódicos de cada uno de ellos en los siguientes meses y las comunidades dependientes, ya de por sí resquebrajadas, se separaron completamente. A pesar de las disculpas ofrecidas por el Arzobispo en distintos medios, el diario comunista Panvor (El Trabajador, editado por la HOG) publicó una carta del prelado donde afirmaba haber quitado la bandera porque la consideraba una manifestación de revuelta y desdén hacia la actual organización estatal de Armenia (Atamian, 1955: 362). 


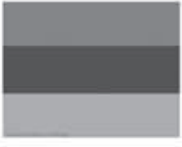

(1918-1920)

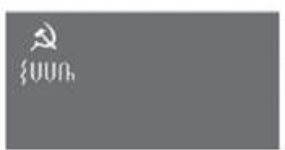

(1940-1952)

\section{CCPA}

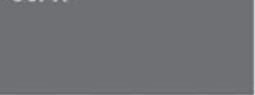

(1922-1937)

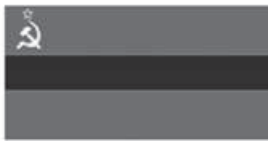

(1952-1991)
\$)

\{rous

(1937-1940)
En ese clima de confrontación se celebró en Nueva York (Estados Unidos) la convención anual del concilio de la Iglesia Apostólica Armenia de América donde se planteó la destitución del Arzobispo. Los delegados estaban divididos. El grupo pro-soviético tenía mayoría (gracias al voto de los pastores), pero se buscaba la aprobación de nuevos delegados que darían mayor peso político al grupo del Tashnaksutiún. En un clima de incertidumbre se evitó el nombramiento de los nuevos delegados y se procedió a la ratificación de Levón Tourián como Arzobispo. Sin embargo, el grupo del Tashnaksutiún organizó una convención paralela donde sí se destituyó a Tourián. Ese fue el origen del cisma en la Iglesia Apostólica Armenia de América, una especie de Avignon (Atamian, 1955: 366).

Etchmiadzín optó por aceptar el cisma y considerar a un grupo como oficial (la Iglesia del Tashnaksutiún) y al otro como autorizado (el grupo pro-soviético), surgiendo dos prelados en Estados Unidos. El grupo pro-soviético (HOG, comunistas, ramgavares e hnchakianes) formó un Frente Unido que declaró la guerra a la bandera tricolor y al Tashnaksutiún, pregonando una campaña de desprestigio contra los miembros de ese partido.

Esta era la crisis que existía cuando el 24 de diciembre de 1933, durante la misa de Navidad, el arzobispo Tourián fue asesinado camino al altar en la Iglesia de la Santa Cruz en Nueva York. Había nueve miembros del Tashnaksutiún durante la celebración y en un juicio, que se dice estuvo plagado de inconsistencias y turbiedades, se decidió que dos de ellos (Leylegián y Sarkissián), a pesar de que ningún asistente a la misa "vio nada", fueran sentenciados a pena de muerte, luego conmutada a cadena perpetua. La comunidad del Tashnaksutiún no creyó que ellos fueran los asesinos, incluso empezó a calificarlos como héroes (para los militantes de ese partido los actos violentos en defensa de la causa son heroicos) y mantuvo un apoyo constante a sus familias.

La controversia surgida a raíz del asesinato de Levón Tourián fue una muestra, la más espectacular, de esa diferenciación y disputas que han sido la norma desde el establecimiento de las conmemoraciones en 1921, y que provocó la imposibilidad de realizarlas de manera unificada. Los hechos de 1933 han dejado marcas en las comunidades armenias; desde entonces se mantiene una especie de devoción hacia esas polaridades. Todo armenio tiene que escoger (aunque muchas veces es hereditario) entre ser de un grupo o del otro (la opción neutral también existe) y es muy común que al indagar sobre otro armenio surja la pregunta: ide qué lado está?

Los actos de conmemoración del 24 de abril en estos primeros años se hacían por personas que había vivido el sufrimiento, eran los confesores del martirio armenio quienes mantenían una memoria, quizá borrosa, por sus seres queridos quienes murieron durante el genocidio. Los sobrevivientes, cargando sin duda con traumas profundos, enseñaban el pasado a las jóvenes generaciones dejando vacíos en sus historias y truncados sus relatos, pero la transmisión se hace con fragmentos expresivos y con mucho silencio.

La nueva cohorte nacida en los contextos del desplazamiento (países anfitriones) y que no experimentó personalmente el genocidio es la que recibe el mensaje transmitido y le proporciona dos posibles salidas: el olvido o la militancia de la memoria. Mientras que muchos armenios de la segunda generación dejaban a un lado la rememoración y le daban la espalda al pasado bebiendo la droga del olvido (como sucede con la comunidad armenia de México y que de alguna manera implica la pérdida de la identidad), otros hicieron de la fecha un momento de mayor combatividad de cara 
a Turquía y a la comunidad internacional, empezando por las sociedades donde nacieron y a las que pidenexigen un reconocimiento de su desdichado pasado. El quiebre generacional permite una resignificación del 24 de abril. La forma como se conmemoraba comenzó a ser cuestionada por su obsolescencia de frente a las nuevas características del mundo y de las comunidades armenias. La nueva generación produjo una dinámica conmemorativa diferente en la cual los símbolos y la interpretación del 24 de abril comenzaron a modificarse. Fue a partir de los primeros años de la década de los sesenta cuando se tuvo un cambio importante.

\section{Las manifestaciones por el cincuentenario y la lucha por el reconocimiento: 1964-1975}

La conmemoración en el seno del gueto dispersivo empieza a ser cuestionada por esa nueva cohorte, algunos con formación universitaria, que se distancia de las imágenes familiares y añoradas, pero enquistadas en el pasado reciente. Lo anterior permite la reformulación de otras formas ideales que también sirven de ejemplo; es un momento en el cual se redefinen las causas y se vislumbra un nuevo destino para la lucha armenia. Es el instante cuando la generación que siguió al genocidio se apropia del acto y lo re-significa. Al mismo tiempo impide el olvido pero también lo instala en los contextos anfitriones. La memoria es una promesa de fidelidad que sella el vínculo social de pertenencia común entre dos generaciones: "prometo que recordaré tu sufrimiento y desgracia, prometo que no olvidaré ni te olvidaré, prometo que recordaré la injusticia”. La memoria de la injusticia se modifica y permite encontrar nuevos cauces y formas de combate por la justicia.

Es a partir de este momento cuando podemos hablar de una instalación del 24 de abril en el quehacer comunitario. Dicha instalación implica "promover una interpretación de los hechos y conmemorarlos, mediante las convocatorias a actos públicos, las publicaciones y el debate político y social, actuando no sólo en la conmemoración de un Nosotros que conoce la verdad, sino para instalarla en la memoria de los Otros, sean los indiferentes o los antagónicos" (Candina, 2002: 12).

La influencia del ámbito internacional es importante en este periodo de la historia armenia. Los juicios de Nuremberg, el nacimiento del vocablo "genocidio" en 1943, la Convención para la Prevención del Crimen de Genocidio de 1948, la revolución cubana y la independencia de muchas colonias, la figura del Che Guevara y la guerra en Vietnam, pero sobre todo el accionar político judío al conseguir que Alemania reconozca el genocidio cometido durante la Segunda Guerra Mundial y tenga reparaciones inmediatas hacia las víctimas de la Shoá, coadyuvan a que el engranaje armenio que exige justicia se destrabe de cincuenta años de memoria intramuros.

Las diferencias latentes entre el grupo del Tashnaksutiún y el contra-Tashnaksutiún se mantienen en todos los niveles, pero la nueva generación se percata de que para sacar el duelo del gueto y poder instalarlo en los espacios del desplazamiento es necesario sentarse en la mesa y lograr acuerdos de acción conjuntos. Fue en Montevideo (Uruguay) donde por vez primera se logra formar un movimiento que busca un entendimiento entre los distintos grupos, la denominada Mesa Coordinadora ${ }^{22}$ de Organizaciones Juveniles del Uruguay (desde ahora la Mesa). Es la primera organización que de manera conjunta busca promover la movilización total de la diáspora para tener demandas ante Naciones Unidas, el reconocimiento del genocidio, que Turquía indemnice a los sobrevivientes y devuelva los territorios usurpados. Uno de sus más importantes logros fue el camino iniciado para instalar el acto de manera pública y buscar que los representantes del Estado anfitrión se manifiesten:

Los jóvenes armenios nacidos en tierra uruguaya nos dirigimos a la opinión pública de nuestro país, seguros de contar con su apoyo sincero en este acto de sentida recordación y de reclamo de los auténticos 
derechos del milenario pueblo armenio (comunicado de la Mesa en el diario El País, 24 de abril de 1964, apud Karamanoukian, op.cit.).

En 1965, cincuentenario del genocidio, la Mesa declara en un comunicado (4 de enero de 1965) que mantiene los reclamos de la causa armenia, que el cincuentenario es una fecha especial para reavivarla, que la causa armenia es de todos los armenios y por consiguiente su trabajo debe hacerse de manera conjunta con un solo frente y objetivo. La Mesa logró aglutinar a la mayoría de los partidos, iglesias y organizaciones armenias de Uruguay, rompiéndose así con la maldición de 1933. Se dedicó a preparar la conmemoración del cincuentenario y a difundir conferencias sobre cultura e historia armenias.

La instalación del genocidio en el espacio público uruguayo se manifestó también en un concurso de afiches (pósteres) que serían pegados en las calles de Montevideo a la par de la multitudinaria marcha silenciosa que, sin polémicas banderas, logró aglutinar a casi toda la colectividad. La marcha se realizó el 23 de abril por la Avenida 18 de julio, desde Plaza Cagancha hasta Plaza Independencia donde se colocó una ofrenda floral ante el monumento al líder independentista uruguayo José Gervasio Artigas. El sábado 24, después de la misa en la Iglesia Apostólica Armenia, se colocó la piedra fundamental del monumento a los mártires.

Pero más allá del hecho de sacar el duelo al espacio público, el logro más importante de la Mesa fue hacer que el gobierno de Uruguay reconociera mediante un acto jurídico el genocidio armenio, convirtiéndose en el primer Estado en el mundo en hacerlo. Por si fuera poco, marcó una pauta de accionar político para que el resto de la diáspora armenia instalara la causa en otras agendas de la política internacional.

El artículo primero de dicha ley uruguaya ${ }^{23}$ considera al 24 de abril como "Día de recordación de los mártires armenios". En la exposición de motivos plasmada en las actas de la Cámara de Representantes, ${ }^{24}$ además de calificarse de genocidio es comparado con el holocaus- to judío. También se considera a los armenios como un pueblo minoritario al cual se quería eliminar pero que, sin embargo, "siguen manteniendo vivo el espíritu nacional que determinó su sacrificio, siguen aferrados a su religión, a sus costumbres...."

El martirio armenio es considerado nacional pero todavía mantiene un pie en lo religioso. Tardó 44 años para que la mención a mártires pasara de la resolución eclesial de Etchmiadzín a una ley en un Estado anfitrión; el uso político de la memoria de injusticia entra por fin a la arena internacional. A pesar de que el partido Tashnaksutiún haya sidoel abogado más perseveranteen la política de memoria del 24 de abril, fue gracias al apoyo y coordinación de todos los grupos que se logró instalar por vez primera y definitiva en los espacios anfitriones de la diáspora.

Sin embargo, la Mesa era una amenaza para el control de los cotos de poder que tenían los partidos políticos en Montevideo, dependientes de la sede sudamericana asentada en Buenos Aires. Fue de ahí de donde se lanzaron intentos infructuosos para cooptar a la Mesa; al final se decidió desaparecerla. La gerontocracia se sentía cómoda con el escenario, todavía vigente, de Montescos y Capuletos, pero la revolución en el planteamiento de la "nueva" causa armenia ya había comenzado. Las conmemoraciones siguientes en Montevideo volverían a ser realizadas por los dos grupos antagónicos de manera separada, sólo que ahora públicamente en plazas y calles de la ciudad, invitando a personajes de la política uruguaya, incluidos los militares durante la dictadura.

El acto de tomar las calles no fue exclusivo de Montevideo. En Yereván, en la Armenia soviética, hubo una marcha multitudinaria el 24 de abril de 1963 organizada por la Unión de la Juventud Armenia. Tuvo como pie de entrada el reclamo de mayor protección de la lengua armenia (se entiende que frente al ruso), realizada ante el edificio del Partido Comunista de Armenia. Los dos años siguientes las demandas escalaron hasta tomar las calles el 24 de abril de 1965 exigiendo "nuestras tierras, justicia, independencia nacional" (Kasbarian-Bricout, 1984: 232). Lograron que el gobierno soviético construyera un mo- 
numento a los mártires del genocidio de 1915, en la colina llamada Fortaleza de las Golondrinas (Tzitzernakapert), en Yereván, lugar que desde entonces es el monumento emblemático de los mártires armenios.

Pero la intensa memoria colectiva de injusticia no sólo reacciona con formas políticas pacíficas como las ocurridas en 1965. Para algunos miembros de la tercera generación (en su mayoría provenientes de Medio Oriente ${ }^{25}$ e influidos por el combativo contexto palestino y libanés), las luchas por la justicia y por la memoria también se hacen de manera combativa, como decía un miembro del Ejército Secreto Armenio para la Liberación de Armenia (ESALA) en una entrevista en Beirut: "porque nuestros padres trataron de hacer reconocer por medios pacíficos el crimen que nuestro pueblo había sufrido, en vano". ${ }^{26}$ Para cambiar esa política "inútil" usaron algunos paradigmas de acción que están presentes en la tradición política armenia: el terrorismo de los justicieros. ${ }^{27}$

Las ejecuciones de los mártires terroristas: 1975-1988

La Federación Revolucionaria Armenia tuvo un viraje influida, en parte, por los aprendizajes de 1965 y, también, por los cambios en el escenario mundial, especialmente la guerra de Líbano, lugar de asentamiento de una de las comunidades armenias más populosas. Después de su XX Congreso en 1972, se lanza una "revolución cultural haitadista", de Hai Tad o causa armenia, cuya finalidad es luchar contra la asimilación a las sociedades anfitrionas (denominada matanza blanca) de las nuevas generaciones nacidas en la diáspora (Minassian, 2002).

La lucha y resistencia contra la Unión Soviética entra en un periodo de distensión y las energías se canalizan hacia el enemigo ancestral, Turquía; se busca atacar a sus representantes diplomáticos y consulares. Pero también preserva la lucha pacífica que había iniciado desde 1965 a través del Comité de Defensa de la Causa Armenia (CDCA), cuya finalidad es el reconocimiento del genocidio por parte de las potencias occidentales y los organismos internacionales.
Así, la lucha se desarrolla en dos frentes: uno pacífico y coordinado por la CDCA y otro combativo y clandestino que, tomando como ejemplo a los justicieros de antaño, es representado en un primer momento por el Comando de Justicieros del Genocidio Armenio (CJGA y posteriormente remplazado por la Armada Revolucionaria Armenia, ARA) de filiación tashnak (Tashnaksutiún). Sin embargo, rápidamente surgirá un movimiento más extremista y partidario de la revolución mundial: el Ejército Secreto Armenio para la Liberación de Armenia (ESALA), fundado en Beirut el 20 de enero de 1975. Finalmente, después de 1983 los grupos terroristas entran en una lucha fraticida y se escinden en distintos grupos. Esta nueva fase del terrorismo armenio empieza en 1973 con el asesinato (para vengar la muerte de su familia 58 años atrás) de dos trabajadores del consulado turco en Santa Bárbara (California) por el septuagenario Kurkén Yanikián; en los siguientes años, 35 diplomáticos turcos perdieron la vida en atentados perpetrados por jóvenes armenios. Los grupos terroristas que iniciaron sus actividades en 1975 rápidamente se apropiaron de la figura de Yanikián, calificándolo de fedayín y transformándolo en ejemplo admirable. Su nombre fue asociado al de Tehlirián, Chiragián o Yerganián, los justicieros del grupo Némesis de la década de los años veinte.

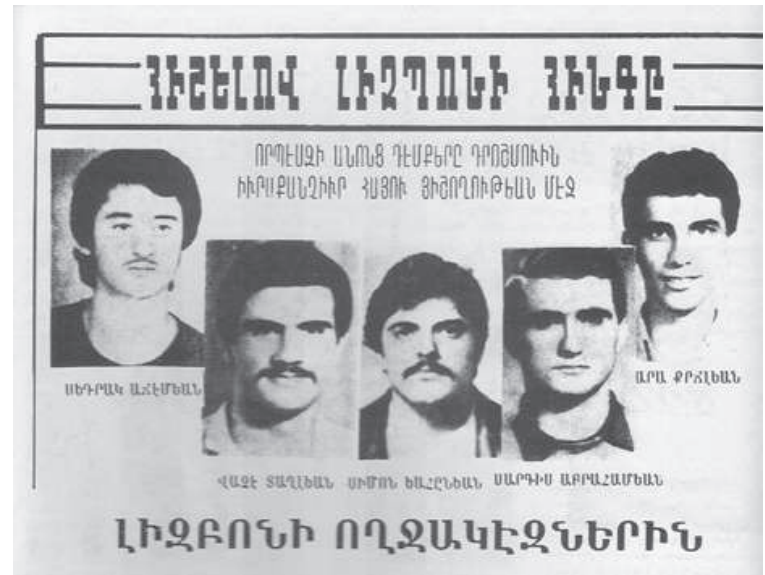

Los Cinco de Lisboa 
Sin embargo, uno de los actos terroristas que más cautivó la atención armenia a nivel internacional fue la toma de la Embajada turca en Lisboa el 27 de julio de 1983 por el grupo terrorista ARA; los cinco jóvenes (entre 19 y 25 años) murieron cuando se detonaron los explosivos que llevaban, sin presentar resistencia ante las fuerzas de seguridad portuguesas. Mientras los encabezados de los diarios hablaban del suicidio de los cinco justicieros de Lisboa, ARA declaró que "no se trataba de un suicidio ni de la expresión de una locura, sino que sus miembros se sacrificaron en aras de la libertad" (según un mensaje dejado en el buzón de la agencia de noticias Associated Press), de la misma manera como lo hicieron las "víctimas caídas en el altar de la libertad" mencionadas en 1930 en el periódico Hairenik, refiriéndose a los fedayínes o a los justicieros.

Rápidamente, su acción fue calificada de heroica por algunos grupos de jóvenes, como la filial Tehlirián de la Unión de la Juventud Armenia del Tashnaksutiún en Buenos Aires que invitaba, el 19 de agosto de 1988, a ver el video de los últimos testimonios de los cinco de Lisboa con una hoja volante que decía: “"sacrificio, concientización y convicción de lucha': éste es el legado de nuestros héroes". El mensaje continuaba doce años después en uno de los periódicos del Tashnaksutiún: "Fue el acto más sublime, que reflejó el espíritu de la tercera generación de la Diáspora. Fue la cristalización del idealismo, que se transformó en objeto de culto para la juventud armenia comprometida y de asombro para los círculos extranjeros" (Armenia-patzarik, 2000). Para este grupo político los actos terroristas eran vistos como operaciones de guerra civil, por consiguiente, loables.

La emergencia y la utilización de los medios masivos de comunicación permitieron que las demandas de estos jóvenes terroristas llegaran a casi todo el mundo: era una de sus estrategias principales. ${ }^{28}$ Definitivamente, lo lograron, como decía el portavoz de la CDCA de Francia en 1982: "Todo lo que podían soñar los armenios, con sus manifestaciones y sus declaraciones, era a quince líneas en LeMonde. Hoy, cuando abren los periódicos, ellos leen quince páginas" (apud Hemelin y Brun, 1983: 230).
Establecer la cuestión armenia en la mesa de la opinión pública fue uno de los grandes logros de la emergencia terrorista. Entre los lectores estaban el pueblo turco (que podría cuestionarse sobre la versión negadora del genocidio de su gobierno) y la opinión pública de las potencias mundiales, pero también el armenio de segunda y tercera generaciones, nacido en la diáspora y quizá asimilado o a medio asimilar, que observaba con cautela pero con cierto apoyo emotivo y simpatía el accionar terrorista.

Dicho apoyo respondía a que el accionar de los terroristas tenía muchos mensajes que el armenio recibía con una especie de sentimiento de orgullo. Especialmente la noción de sacrificio que había sido y que es una pieza clave de su identidad y de su relación con la comunidad armenia. Además, los mensajes utilizados por los terroristas eran fácilmente entendidos, ya que éstos usaban nombres para sus acciones que inmediatamente eran identificados por quienes tuvieran un conocimiento aparente de la historia y cultura armenias; se utilizaban narraciones del genocidio, además de la del mártir Vartán del año 451 d.C. ${ }^{29}$ Por ejemplo, la operación en el aeropuerto turco de Ankarafue llamada Garin, el nombre armenio de la ciudad "usurpada" de Erzerum. Algunos comandos fueron bautizados con nombres como Antranik Pashá (unfedayín-revolucionario de la época del genocidio y la primera República) o Yanikián (el septuagenario que inició los atentados terroristas en 1973). Los pseudónimos hacían referencia al genocidio, a los fedayines y a los justicieros, pero también al 24 de abril en general, como el caso de una de las portadas de un periódico del grupo terrorista ESALA donde se aprecia una fotografía con cráneos de los masacrados en 1915 y una inscripción que dice: "Que el 24 de abril se convierta en una fecha de lucha" (apud Tölölyan, 1987b: 227).

Las publicaciones de los grupos terroristas no dudaban, como tampoco lo hacían las publicaciones tashnaks de principios del siglo XX con respecto a los fedayines, de calificar a los muertos en los atentados de mártires, usando la secularizada y revolucionaria fórmula de nahadag-engers (mártires-camaradas) y calificándolos de fedayines: 
El fedayín Meguerdich Madurian completó su misión antes de que explotara una granada que cargaba pegada a su pecho, enseñando con esto que el Ejército Secreto está determinado a continuar en la senda de la muerte deliberadamente escogida. ${ }^{30}$

La "muerte deliberadamente escogida" está escrita en armenio clásico de la misma manera como lo está en la Epopeya de Vartán, de manera que explícitamente se hace un paralelismo entre el "terrorista” y el mártir Vartán. Los mártires de Vartanantz, como los del genocidio y los terroristas que adoptan la narración del martirio al morir en defensa de la armenidad, lo hacen por la dupla patria-religión. Para los terroristas y sus simpatizantes, todos ellos murieron por Armenia. Una nota aparecida en el diario tashnaksagán Armenia de Buenos Aires resume lo que hemos mencionado:

En la historia de los pueblos hay hechos que permanecen sellados a fuego en la memoria colectiva, que se transforman en hitos que fundamentan el carácter de un pueblo, y su trascendencia es tan profunda que llega a elevarse hasta el grado de ideal. (...) Y sólo cuando un pueblo se identifica con él, lo sostiene y llega a corporizarlo, aquél ideal alcanza a tornarse realidad. De esta forma, luego de la Epopeya de Vatanantz, en la realidad del pueblo armenio quedó grabado el concepto del sacrificio conciente. Pero no siempre se plasmó en realidad. Debieron pasar algunos siglos para que surgiesen generaciones concientes de la necesidad del sacrificio supremo en pro de la liberación nacional, y se difundiese la "audacia" revolucionaria transmitida por Kristapor, ${ }^{31}$ para que así resurgiese triunfante ese ideal del sacrificio conciente. Desde este punto de partida nos retrotraemos diecisiete años atrás, para recordar el heroico acto de Vaché Daghlian, Ará Kerdjalian, Setrak Adjemian, Sarkís Aprahamian y Simón Yahnian, los cinco jóvenes del Ejército Revolucionario Armenio inmolados en la Embajada turca de Lisboa" (Armenia-patzarik, diario Armenia, núm. 12849, noviembre de 2000: 37).
Los terroristas que ajusticiaron a diversos cónsules o embajadores turcos eran objeto de veneración. Un activista de la causa armenia en Buenos Aires me comentó ${ }^{32}$ que el día que conoció en la cárcel a Kurkén Yanikián, le preguntó que con cuál mano había disparado, antes de besarla. Este respeto también sucedía con el justiciero y comandante de milicia Dro, quien mató a un "odiado" oficial zarista en 1903 y a quien, según cuenta en sus experiencias en Siria Khachig Tölölyan (1992), los armenios se aproximaban para besarle la mano, avergonzándolo. Este culto a los actos violentos realizados por la causa armenia se manifestaba en novelas, poemas y trabajos artísticos de toda índole en la mayoría de las comunidades dispersas, fundamentalmente en el seno del grupo tashnak. Y es que la simpatía que producen los terroristas responde a su sacrificio o disposición a una muerte heroica, en nombre de la comunidad en su conjunto.

El contexto cultural del terrorista es fundamental para entender la utilización que se ha hecho de los actos violentos por parte de su comunidad, un uso que puede remontarse a muchos años en el tiempo. Como vimos en el caso armenio, las acciones de venganza realizadas entre 1921 y 1923 bajo la égida de la operación punitiva Némesis, cuya finalidad era matar a los responsables del genocidio, emerge con la tercera generación; pero ahora su blanco es el servicio diplomático turco que representa a un gobierno que no ha dejado de negar el genocidio.

La venganza de los justicieros armenios de los años veinte, como el terrorismo de 1975-1988, son una respuesta al genocidio. Tanto los justicieros de antaño como los terroristas de este último periodo están al servicio de la causa armenia; ambos han salido de las filas del Tashnaksutiún y son considerados héroes dispuestos a sacrificarse por Armenia. Quienes mueren serán calificados de mártires equiparándolos con las víctimas masacradas durante el genocidio.

El uso político de esta figura heroica se construye con base en referentes o modelos paradigmáticos de comportamiento anteriores, el mismo referente que la Iglesia armenia había utilizado por siglos para mantener 
una cohesión social ante un espacio de subyugación, proclive a la asimilación. Y es que ahora la vida de la mayoría de los armenios está en contextos dispersos y en un espacio que también asimila. El combate y conflicto con los contextos de asimilación (los países anfitriones de la diáspora), en aras de supervivencia, utiliza como figura ejemplar a esos individuos que se sacrifican, que mueren en nombre de la causa para mantener y conservar lo armenio, ya sea ante las fuerzas genocidas o ante los gobiernos que le sucedieron.

Aunque se encuentren en planos distintos en cuanto a su tipo de accionar, el fedayín del siglo XIX combate y muere en defensa de su nación: la víctima del genocidio sucumbe de manera pasiva, mientras que el terrorista muere por la causa de la justicia; todos se sacrifican y, por consiguiente, se convierten en figuras ejemplares, no tanto imitables sino admirables. Como dice Tölölyan, son nuevos héroes para viejas historias. Esa admiración es construida políticamente usando modelos ejemplares que ayudan a conservar una memoria de identidad en los contextos de asimilación, y son un rasgo histórico de la identidad armenia que se recrea a través del tiempo.

Cada 24 de abril podemos ver algunas de sus manifestaciones. Y es que los atentados terroristas tuvieron una influencia profunda en las sociedades anfitrionas como Francia, donde algunas conmemoraciones fueron reprimidas por la policía. Tal fue el caso de la ocurrida el 28 de abril de 1978 en París, cuando logró producirse el primer debate sobre el genocidio armenio en el Parlamento francés. Mientras que de 1962 a 1976 sólo hubo una sólo mención al genocidio en el Parlamento, entre 1976 y 1981 hubo 22, y finalmente en 1981 el gobierno francés "reconoce" el genocidio armenio: "Los armenios viviendo en el Imperio Otomano fueron víctimas de un genocidio" 33 (Hamelin y Brun, 1983: 234). Sin duda, la influencia de la política combativa en pro de la justicia articulada por los terroristas-justicieros dio sus frutos en Francia.

La búsqueda de justicia es una de las piezas más sólidas en la política de la memoria armenia. Algo que la tercera generación parece haber demostrado es que la memoria se utiliza, de lo contrario, no sirve. Los atentados terroristas propiciaron un resurgimiento del genocidio armenio en la fecha de su conmemoración, en la cual se usaba constantemente referencias a los nuevos patriotas que se sacrificaban por la causa. Las comunidades entraron en una nueva dinámica más activa. Asimismo, un vasto movimiento en favor del reconocimiento del genocidio entró en vigor, al constituirse nuevas asociaciones políticas que cabildearon en pro de la causa armenia; este movimiento terminó por instalar la fecha del 24 de abril en los contextos anfitriones.

Pero el terrorismo, al materializarse en acciones que mataban a "civiles inocentes" a partir de 1980, al cometer atentados a compañías aéreas extranjeras, terrazas de café, estaciones de trenes, restaurantes McDonald's y aeropuertos — como el "más grande" atentado ocurrido en Francia (el 15 de julio de 1983 en el mostrador de Aerolíneas Turcas del aeropuerto de Orly), que dejó siete muertos y 57 heridos-, empezó a perder "simpatía" (un efecto desmovilizador) por parte de muchos armenios. Además, el grupo anti-tashnaksagán recriminó el atentado desde un principio, como también lo hizo el tashnaksagán Movimiento Nacional Armenio "por razones humanitarias y morales, pero también políticas: la causa armenia ya es conocida; esta forma de terrorismo corre el riesgo de convertirla en incomprensible". ${ }^{34}$

Desde entonces empieza a verse un proceso de descomposición del movimiento terrorista, además de la escisión en grupúsculos y una pérdida de rumbo en el objetivo inicial (matar diplomáticos turcos), que era el que aglutinaba a los simpatizantes al ser visto como un acto de legítima defensa. Los terroristas empezaron a ser considerados una amenaza a la imagen de la causa armenia y un motivo de aislamiento de las comunidades armenias del resto de la población (Hamelin y Brun, 1983: 244). Las menciones "disimuladas" que se hacían de su actividad en las conmemoraciones del 24 de abril empezaron a ser eliminadas.

Para 1988 la heroificación de los terroristas como mártires desapareció, especialmente porque ocurrió el 
estallido del conflicto por el enclave armenio de Nagorno Karabagh en Azerbaiján. Se trata de un enclave con población mayoritariamente armenia que a partir de 1988 buscó su unificación con la entonces República Socialista Soviética de Armenia, declarándose independiente de Azerbaiján, tres años antes de que esta República musulmana también se independizara en 1991, luego de la desaparición de la Unión Soviética. Entre 1992 y 1994 libró una guerra de secesión (aunque todavía permanece como zona en disputa y en estado de conflicto latente) y algunos de sus soldados (autonombrados fedayines), al morir por la patria pero también por la religión cristiana al combatir a un Estado musulmán, son considerados mártires. La utilización del martirio entre los armenios sigue brindando viejos héroes para nuevas historias.

\section{Conclusiones}

Elgenocidio armenio es un gran problema de un pueblo pequeño, motivo por el cual ha sido olvidado por la mayoría de los Estados que controlan el escenario mundial. Sin embargo, la política de esa "sagrada memoria" que han logrado los armenios durante 93 años es un ejemplo de cómo las luchas de las minorías pueden mantenerse a través de la militancia de la memoria: y es que de alguna forma olvidar es dejar la puerta abierta a nuevos genocidios.

El eje de las conmemoraciones del genocidio armenio de 1915 va desplazándose de acuerdo a las coyunturas. De la visión melancólica y silenciosa que permeaba las conmemoraciones entre 1921 y 1965, se produce un cambio importante al cumplirse los cincuenta años del genocidio en 1965. Entonces las manifestaciones se hacen públicas y buscan el reconocimiento por parte de los Estados anfitriones. La siguiente generación (1975-1985), nacida en las sociedades anfitrionas, propicia nuevamente un cambio importante en la búsqueda del reconocimiento y en contra de la negación del genocidio por parte de Turquía; para ello utiliza al terrorismo como estrategia y herramienta de combate. La combatividad de la causa armenia fue adecuándose con el tiempo y las circunstancias al grado de modificar las figuras ejemplares que ayudan para mantener la memoria.

La figura ejemplar instrumentada en contra del peligro y que ayuda a la cohesión nacional armenia es la de mártir; pero dicha figura heroica es construida con base en la influencia de distintos acontecimientos, de manera que el uso político que se hace de ella se modifica con el tiempo. La figura del mártir armenio ha pasado de su forma religiosa primigenia a una forma de combate por la causa armenia, pasando por periodos de silencio, combate terrorista y lucha armada. Este proceso de transformación de una figura ejemplar, una especie de revisión del icono o héroe fijado en la memoria, puede verse en las conmemoraciones, manifestaciones y actos terroristas realizados por armenios para recordar el genocidio sufrido en 1915, rememorado el infeliz día del 24 de abril.

Las expresiones que se articulan se rigen por algunas constantes y diversas modificaciones, que se manifiestan a lo largo de las conmemoraciones y que son visibles si se les compara año con año. La importancia que para los armenios tiene el 24 de abril hace de esta fecha un instrumento útil para ver la historia de la diáspora armenia, pero también para apreciar las distintas transformaciones experimentadas por una comunidad con ochenta años de vida en los contextos del desplazamiento. Son fechas que pueden ser leídas como tradiciones inventadas, eficaces para unificar sentimientos e interpretaciones del pasado, a partir de las cuales se puede instrumentar la expresión de identidad que da una cohesión social que permite estructurar relaciones sociales dentro de una comunidad o sociedad (Carvalho y da Silva, 2002: 196).

Por este motivo, el análisis de los variados escenarios en una fecha particular, que en el caso armenio ocurre en los cinco continentes, permite ver el funcionamiento de una red comunitaria dispersiva 
articulada con un sentido de causa unificado, además de observar las diferentes adecuaciones a las circunstancias específicas de cada comunidad. Es decir, a pesar de tener un sentido y motivación comunes, cada comunidad "representarâ" su conmemoración de manera específica, en respuesta al contexto anfitrión y a sus particularidades intrínsecas. Pero en todos los casos hará del mártir un ejemplo loable al que hay que admirar.

\section{Notas}

${ }^{1}$ Antes de 1914, la civilización armenia había existido en la planicie armenia por casi dos milenios. Se convirtieron al cristianismo en el año 301, lo que los hace el Reino cristiano más antiguo. Tienen una Iglesia autocéfala, un idioma particular indoeuropeo y un alfabeto propio. Conquistados por romanos, árabes, mongoles, griegos y hacia 1050 por los turcos. Desde el siglo XIV no tuvieron ningún Reino o Estado propio, sin embargo el pueblo armenio vivía relativamente seguro como minoría étnica al interior de diversos imperios. De 1918 a 1920 formó en 10\% del territorio habitado por armenios una República independiente que cayó bajo el dominio soviético de 1920 a 1991, desde ese año existe una independiente República de Armenia. Sin embargo, aquellos sobrevivientes del genocidio que emigraron a diversos países, y sus descendientes, mantienen una sólida identidad y suman una población mayor a la de los armenios de la República de Armenia.

2 300,000 dice El-Ghusein, 1918: 4.

${ }^{3}$ El cual sería refundado en 1921 en El Cairo (Egipto) con la fusión del Hnchakián reformado y antiguos miembros del Armenagán.

${ }^{4}$ Mapas elaborados por Emmanuel Ramírez y Carlos Antaramián a partir de fuentes diversas, especialmente Hewsen (2000).

${ }^{5}$ Antes que Roma (3ll d.C.), Armenia fue el primer reino cristiano.
${ }^{6}$ Como el 11 de septiembre en Chile (aniversario del golpe de Estado de 1973), 24 de marzo en Argentina (aniversario del golpe de Estado de 1976), 14 de abril en Uruguay (fecha conmemorada por la dictadura para recordar a los caídos en la lucha contra la guerrilla), 3 de noviembre en Paraguay (aniversario del nacimiento del dictador Stroessner, que funcionó como referente de conmemoración nacional durante la dictadura y que después de derrotada se convirtió en una fecha de contienda política) o el 31 de marzo en Brasil (aniversario del golpe de Estado de 1964). Son fechas que los gobiernos militares buscaron justificar para que los ciudadanos se identificaran con ellas; sin embargo, también fueron reivindicadas y disputadas por los grupos reprimidos que las hicieron suyas y les dieron el valor de conmemoración trágico, como se reconocen actualmente. Las víctimas y los victimarios interpretan estas fechas de manera diferente.

7 "En este contexto, la negación que acompaña al proyecto genocida se convierte en la pieza maestra, dado que, más allá del exterminio de las personas, tiene la función de sostener la desaparición de su existencia pasada a fin de que se transformen no en muertos, sino en 'quienes jamás existieron'. Entonces, ante toda esa muerte (la muerte de ellos) y en cuanto sus herederos, los sobrevivientes hacen suyo el deber de permanecer no ya en el campo de la vida sino en el aún más fundamental de la existencia y la necesidad, que va a forzarlos, si quieren retener a esos muertos al margen de la existencia, a no tener otro presente posible más que el tiempo en que aquella muerte se produjo, suspendido y a la vez retomado indefinida e intemporalmente" (Piralian 1994: 20).

8 “... el negacionismo ha fortificado el sentimiento étnico armenio. Porque se revelan contra la injusticia, contra el crimen capital cometido por un Estado que pretende ser democrático, [que] por muchas décadas niega el crimen. Es un fenómeno muy importante, yo pienso que si Turquía hubiese reconocido el Genocidio y hecho repara- 
ciones, la mitad de los armenios de la diáspora hubieran olvidado todo, se hubieran asimilado. El negacionismo turco ha contribuido a preservar la identidad armenia. Más que los partidos políticos, más que la Iglesia” (entrevista Carlos Antaramián-Vahakn Dadrian, Buenos Aires, 12 de agosto del 2000).

${ }^{9}$ Llamado Catolicós, acentuado en la segunda o.

${ }^{10}$ Hubo una confusión en la fecha al trasladar el calendario juliano al gregoriano.

${ }^{11}$ Bajo el veredicto del Noveno Congreso del Tashnaksutiún celebrado en Constantinopla fueron descritas como "Operaciones especiales".

${ }^{12}$ Asesinado por Soghomon Tehlerián (cuya familia había sido completamente exterminada) el 5 de marzo de 1921 en Berlín. Miembro del Partido Tashnaksutiún, fue detenido, juzgado y declarado no-culpable por el jurado alemán en vista de los crímenes de Talaat. La historia de Tehlerián fue rápidamente transmitida en la red de publicaciones periódicas de la diáspora. El juicio celebrado en Berlín llegó a calificarse como "El Nuremberg armenio” (Simón Vratsián, apud Dasnabedian, 1988: 156).

${ }^{13}$ Continuó su sueño panturquista en Asia Central. Después de unirse a los bolcheviques, se manifestó como un opositor y combatió contra ellos uniéndose a los musulmanes en las revueltas de Bujara.

${ }^{14}$ Abatido por Stepán Dzaghigián, Bedrós der Boghossián y Artachés Kevorkián en Tiflis el 25 de julio de 1922. Uno de los testigos, el famoso Lavrenti Beria, se dice que exclamó: "Eda Dashnakski terror" (apud Dasnabedian, 1988: 157).

${ }^{15}$ Acribillado por el ex fedayín Misak Torlakián en Constantinopla el 28 de julio de 1921.

${ }^{16}$ Fue el único quien escapó a los justicieros, pero fue ahorcado en el otoño de 1926 acusado de querer conspirar contra Kemal Atatürk.

${ }^{17}$ Ya le habían antecedido Cómo matamos de Yerganián (Beirut, 1954), las Memorias de Tehlirián (Cairo, 1955) y El legado de los mártires (Beirut, 1965) (apud Dasnabedian, 1988: 155).

${ }^{18}$ Algunos armenios de la Ciudad de México me han referido que es posible que el salón donde se realizó este acto haya sido el que se encontraba en la esquina de Venustiano Carranza y Correo Mayor en el Centro de la ciudad. Los actos continuaron hasta la década de 1960; desde entonces no se han vuelto a realizar.

19 "Hasta los años 1940-45 en el salón de la escuela se ponía una mesa cubierta de negro como si fuera un féretro, dos velas en la cabecera y en medio un cuadro fotográfico en el que estaban representadas las imágenes de grandes personalidades de la cultura armenia víctimas del Genocidio. Todos llevábamos escarapelas negras. Se hacían recitados alusivos, discursos y se entonaban cantos religiosos" (del testimonio de la familia Boyadjián, apud Kniasian, 1989: 55).

${ }^{20}$ Musa Dagh (entre agosto y septiembre de 1915 y novelada por Franz Werfel en Los cuarenta días del Musa-Dagh), Van (20 de abril-17 de mayo de 1915), Shabin Karahisar (6 de junio-4 de julio de 1915) y Urfá (29 de septiembre-23 de octubre de 1915). También algunos grupos guerrilleros aislados que se sublevaron y mantuvieron una resistencia momentánea al ejército turco.

${ }^{21}$ La tricolor sería usada de 1918 a 1920 y, al independizarse Armenia de la Unión Soviética en 1991, se acordó usar esta bandera por representar al único periodo independiente.

${ }^{22}$ El nombre lo obtuvo bajo influencia de las "mesas coordinadoras" sindicales que existían en ese momento en Uruguay. La Mesa tuvo ejercicios antes de la organización del cincuentenario, como el mes de la cultura armenia en 1963 (Aharonian, 2005).

${ }^{23}$ El redactor principal fue Enrique Martínez Moreno ("Por el Gobierno del Pueblo"). La propuesta también fue firmada por Hugo Batalla, Aquiles Lanza, Alfredo F. Massa, Zelmar Michelini y Alberto M. Roselli.

${ }^{24}$ Informe de la Comisión de Constitución y Códigos del 5 de abril de 1965, tomo 569: 311-313 (apud Karamanoukian op.cit.).

${ }^{25}$ Lugares donde los armenios están separados de la sociedad por restricciones confesionales, también es ahí donde la asimilación es menor y donde se mantienen las tradiciones de manera más intensa, incluyendo 
gran parte de ese culto al sacrificio y el honor a los fedayínes y justicieros.

${ }^{26}$ Citado por Derogy y Buob (1981: 55).

${ }^{27}$ La recuperación de la figura del militante revolucionario (o terrorista en este caso) sucedió también en las celebraciones del 24 de marzo en Argentina. Posterior a 1991 la condición de víctima del desaparecido pasa a un segundo plano y cobra fuerza su valor revolucionario y la causa que lo llevó a ser un enemigo de los militares. La conmemoración se re-significa otorgando un mayor peso a los compromisos de los desaparecidos y no tanto a su condición victimaria (Lorenz, 2002: 80).

28 "Poursuivre sans relâche notre action. Gagner et développer le soutien de l'opinion publique et des partis politiques arméniens", entrevista del Comando al diario armenio Résistence (apud Kasbarian-Bricout, 1984: 239).

${ }^{29}$ Tölölyan (1987b: 231) pone el ejemplo de un poema escrito en la Armenia soviética pero publicado en la prensa tashnak de Canadá y que hace una analogía muy clara entre Vartanantz y los justicieros: "Vengan, armenios, como fue en Tizbon [Ctesifón, la capital persa sasánida], ayer Tizbon hoy Lizbon [Lisboa], vengan, dejen que el Vartán de Avarayr [el sitio de la batalla en 451] se convierta en la maldición del salvaje turco."

30 "Fedayee Megerdich Madurian completed his mission before he exploded a grenade he carried attached to his waist, thus showing that the Secret Army is determined to continue in the path of "death knowingly grasped'." (Tölölyan, 1987b: 228).

${ }^{31}$ Uno de los tres fundadores del partido Tashnaksutiún murió cuando manejaba una bomba que sería dirigida al Sultán Hamid.

${ }^{32}$ Entrevistado el 14 de agosto de 2000 en Buenos Aires, Argentina.

${ }^{33}$ C. Cheysson, ministro de Relaciones Exteriores (30 de noviembre de 1981) y G. Deferre, ministro del Interior (22 de marzo de 1982). También se reconoció el genocidio en un discurso pronunciado el 24 de abril de 1982 ante la comunidad armenia de Marsella (Time, 23 de agosto de 1982), donde se decía que Francia ayudaría a los armenios para que su causa se reconociese sólo si dejaban de lado la violencia (Hamelin y Brun, 1983: 247).

${ }^{34}$ Así lo dijo su director Ara Toranian (apud Hamelin y Brun, 1983: 247).

\section{Bibliografía}

Albert, Jean-Pierre, 2001, "Sens et enjeux du martyre: de la religion à la politique”, en Centlivres, Pierre (ed.), Saints, sainteté et martyre. La fabrication de l"exemplarité, Editions de l'Institut d'ethnologie, Neuchâtel, Editions de la Maison des sciences de l'homme, Paris.

Atamian, Sarkis, 1955, The Armenian Community. The Historical Development of a Social and Ideological Conflic, Philosophical Library, Nueva York.

Balandier, Georges, 1992, El poder en escenas. De la representación del poder al poder de la representación, Paidós, Barcelona.

Binayán Carmona, Narciso, 1996, Entre el pasado y el futuro: Los armenios en la Argentina, Buenos Aires.

Candina Palomar, Azun, 2002, "El día interminable. Memoria e instalación del ll de septiembre de 1973 en Chile (1974-1999)", en Jelin, Elizabeth (comp.), Las conmemoraciones: Las disputas en las fechas "in-felices", Siglo Veintiuno, Madrid.

Carvalho Alessandra y Ludmila da Silva Catela, 2002, "31 de marzo de 1964 en Brasil: memorias deshilachadas", en Jelin, Elizabeth (comp.), Las conmemoraciones: Las disputas en las fechas "in-felices", Siglo Veintiuno, Madrid.

Chaliand, Gérard, 1982, Presentación a La Dette de Sang, Éditions Complexe, Bruselas.

Chiragian, Archavir, 1973, La Dette de Sang, Presentación de Gérard Chaliand, Éditions Complexe, Bruselas.

Dasnabedian, Hrach, 1988, History of the Armenian Revolutionary Federation, Dashnaksutiun 1890/1924, OEMME Edizioni, Milán.

El-Ghusein, Fa'iz, 1918, Martyred Armenia, George H. Doran Company, Nueva York.

Giordano, Christian, 2001, "Gérer l'exemplarité en (re) mettant l'histoire à jour: les saint, les héros et les vic-

104 Revista LiminaR. Estudios sociales y humanísticos, año 6, vol. VI, núm. 2, diciembre de 2008, Tuxtla Gutiérrez, Chiapas. ISSN: 1665-8027 
times", en Centlivres, Pierre (ed.), Saints, sainteté et martyre. La fabrication de l"exemplarité, Editions de l'Institut d'ethnologie, Neuchâtel, Editions de la Maison des sciences de l'homme, Paris.

Hamelin, Arnaud y Jean Michel Brun, 1983, La Mémoire retrouvée, Mercure de France, París.

Hewsen, Robert H., 2000, Armenia: A Historical Atlas, The University of Chicago Press.

Hobsbawn, Eric y Terence Ranger, 1984, La invención de la tradición, Crítica, Barcelona.

Jelin, Elizabeth (comp.), Las conmemoraciones: Las disputas en las fechas “in-felices”, Siglo Veintiuno, Madrid.

Karamanukián, Daniel, 2000, Apuntes para una reconstrucción histórica de la conmemoración del 24 de abril en Uruguay, inédito.

Kasbarian-Bricout, Béatrice, 1984, Les Arméniens au XXè siècle, L'Harmattan, Paris.

Kniasian, Sergio Alejandro, 1991, "La escuela Jrimian de Valentín Alsina: etapa pionera”, en Matiossian, Vartán (ed.), Las comunidades armenias de América del Sur, Instituto de Investigación Armenológica, Buenos Aires.

Lorenz, Federico Guillermo, 2002, “¿De quién es el 24 de marzo? Las luchas por la memoria del golpe de 1976", en Jelin, Elizabeth (comp.), Las conmemoraciones: Las disputas en las fechas "in-felices", Siglo Veintiuno, Madrid.

Mesrobian, Arpena S., 2000, Like one family: the Armenians of Syracuse, Gomidas Institute, Princeton, New Jersey.

Minassian, Gaïdz, 2002, Guerre et terrorisme arméniens, PUF, Paris.

Morgenthau, Henry, 1919, Memorias, Publicación de la Comisión Pro Causa Armenia de la América Latina, Buenos Aires, 1975.

Piralian, Hélène, (1994), Genocidio y transmisión, FCE, Buenos Aires, 2000.
Subirats, Eduardo, 2003, Memoria y exilio, Losada, Buenos Aires.

Todorov, Tzvetan, (1996), El hombre desplazado, Taurus, Madrid, 1998.

Tölölyan, Khachig, 1987a, "Martyrdom as Legitimacy: Terrorism, Religion and Symbolic Appropriation in the Armenian Diaspora", en Wilkinson, Paul y Alasdair M Stewart, Contemporary Research on Terrorism, Aberdeen University Press.

—, 1987b, "Cultural narrative and the Motivation of the Terrorist”, en The Journal of Strategic Studies, Special issue: Inside Terrorist organizations, vol. 10, núm. 4.

Tololyan, Khachig, 1992, "Terrorism in Modern Armenian Political Culture”, en Weinberg, Leonard, Political Parties and Terrorist Groups, Frank Cass, Londres.

Zekiyan, Boghos Levon, 1999, "The Armenian Way to Enlightenment: The Diaspora and Its Role", en Hovannisian, Richard y David N. Myers (ed.), Enlightenment and Diaspora: The Armenian and Jewish Cases, Scholars Press, Atlanta.

\section{Hemerografía}

Aharonian, Coriún, 2005, "El genocidio armenio, noventa años después", en Brecha, Montevideo, 22 de abril de 2005, páginas centrales.

Anónimo (atribuido a Levón Bogosian o V. Sarkisian), “Celebración de Luto de los Mártires”, en Armenios de América, Hairenik, Boston, junio de 1930.

Anónimo, "A diecisiete años de Lisboa", en Armeniapatzarik, Diario Armenia, núm. 12849, noviembre de 2000.

Derogy, Jacques y Jacques Buob, 1981, "Les filières arméniennes”, en L'Express, París, 27 de noviembre de 1981.

"A Cry for Bloody Vengeance", Time, 23 de agosto de 1982, p. 12. 